\title{
THE INFLUENCE OF INTERNAL AUDIT FUNCTION ON PROMOTING EFFECTIVE CORPORATE GOVERNANCE BY USING THE MANAGEMENT SUPPORT IN COMMERCIAL IRAQI BANKS
}

\author{
Hosam Alden Riyadh ${ }^{1}$, Wuryan Andayani ${ }^{2}$, and Mohammed Sami Al-Bayati ${ }^{3}$ \\ ${ }^{1}$ Accounting department, University of Brawijaya \\ ${ }^{2},{ }^{3}$ School of Accountancy, University Utara Malaysia
}

\begin{abstract}
Good governance became a highly topical business issue at the beginning of the 21 st century following a series of large corporate scandals and failures. This paper aims to set the conceptual framework for assessed the effects of internal audit function (IAF) on good governance in the public sector in Iraq. The objective of this paper to evaluate the internal audit function in promoting effective corporate governance among commercial banks in Iraq, While the specific objectives are to analyze the impact of work experience, the positioning, level of independence and the risk identification, measurement and prioritization approach by using management support adopted to internal audit function of commercial banks in Iraq. This paper will try to given that insights to develop the internal audit function in commercial organizations which is an important part of corporate governance reporting since it in a straight line affects the interests of all stakeholders such as customers, suppliers, employees, customers, creditors and government agencies as well highlighting to the need of change in outlook of the organizations team towards the internal audit function bearing in mind the importance of strong internal audit function for the growth of commercial banks which are valuable for the development of Iraq economy.
\end{abstract}

Keywords: internal audit function, Work Experience, Independence, Positioning, Risk, and Management Support

\section{INTRODUCTION}

The Corporate Governance can characterize as the arrangement of principles, practices, and procedures by which an organization is coordinated and controlled, as well essentially entails weight the interests about the much stakeholders between a company, which consists of its shareholders, administration, customers, financiers, suppliers, government and the community. Since corporate governance also provides the framework for obtaining a company's objectives, it encompasses practically every sphere of management, (Shleifer \& Vishny), "A Survey of Corporate Governance," Journal of Finance 52(2) 1997: 738). Corporate governance is assembly together a group of smart, accomplished people around a board table to create high-quality decisions on behalf of the corporation and its stakeholders. Thus, corporate governance is in division a product of legal systems put in place and the legal infrastructure accompanying them. Generally, corporate governance refers to the host of legal and non-legal principles and practices affecting control of publicly held business corporations. Most broadly, corporate governance affects not only who controls publicly traded corporations and for what purpose but also the allocation of risks and returns from the firm's activities among the various participants in the firm, including stockholders and managers as well as creditors, employees, customers, and even 
communities. However, American corporate governance doctrine mainly describes the monitoring rights then associated obligations concerning three most important groups: first; the firm's shareholders, who grant metropolis then have to admit foremost consolidated transactions second; the firm's dado regarding directors, any are chosen with the aid of shareholders after supervising the management of the corporation; and third the firm's senior executives are accountable because of the epoch in conformity with season operations of the corporation, Corporate governance mechanisms may remain classified into two controlling mechanisms: interior then exterior permanency by Kamardin and Haron (2011)\&Doski (2015) \&Yemi (2015).

Internal audit function has helped keeping bad things from happening; ensureing good things can happen help management understand where their risks are, whether the risks are under control and whether the risks are worth taking. Internal auditors evaluate the controls that help organizations to manage risks and ensure controls are in place working and cost-effective by Nagy and Cenker (2002)\&Wan-hussin and Mohammed (2012)\&Ali, Mustafa, and Hanefah (2013). Corporate governance defined as the system by which companies are directed and controlled. On the last few decades, this idea has largely spread from the areas involving academia and also policy making through their function in supervisory the fiscal reporting process audit committees and enhances the caliber of information flow between company's shareholders, potential shareholders, and the managers. According to Abdul Mohammad \& Burnaby (2006) the studies indicate a paradigm shift in the activities performed by internal auditors. Furthermore, they studied that Internal Audit (IA) in the United States of America (USA) has shifted its orientation to a value-adding one. Before the enactment of the SarbanesOxley Act (SOX) of 2002, IA services were focusing on detection rather than prevention. However, after the issuance of the Sarbanes-Oxley Act (2002), IA changed its emphasis to a compliance approach. In other words, the role of internal audit in corporate governance through its services to the board of directors has strengthened after the Sarbanes-Oxley Act.

Scandals (J. Cattrysse, 2005, p 32-34) that occurred in the late nineties of the past twentieth century in major companies, ssuch as the power company (Enron), and the telecommunications company WorldCom, and the other, shook investor confidence and raised questions about how this has allowed large companies to such scandals. This perhaps was the biggest period of accounting fraud in history until then, followed by sweeping regulatory reform. These serious events have shown critical role played by boards of directors in strengthening effective corporate governance, especially as they are the ultimate responsibility for internal control systems in their institutions, where the internal audit function plays a key role in assisting the councils to carry out assignments governance essentially responsible for them.

Similarly in Iraq, as in lots of other countries in the region, the financial sector possesses witnessed substantial changes in the last few several years. The admittance of global banks including the European bank "BNP Paribas" and the Jordanian bank "Arab Bank" exemplifies one amongst those adjustments. The Iraq Commercial Code (LCC) 1997 Sep 29 required Iraq public enterprises to have internal audit departments headed by directors. This particular code also compels public enterprises to appoint external auditors. Moreover, since the issuance of the Law, Iraq public enterprises are required to undergo audit by general auditors. However, in Iraq there are no professional standards or international professional bodies for IA such as the IIA, which results in organizations establishing their own guidelines on the practice of IA (Al-Kilani 2002; Allegory 1998). Therefore, this study is concerned with internal audit IA effectiveness within commercial Iraqi banks. The research issues addressed by the present study are outlined within this introductory chapter. In addition, the basic elements of the research plan are presented. Based on the previous discussion the problem arises regarding the effect of work experience, independence, positioning, and risk of the influence of internal Audit function in promoting effective corporate governance and as a key role in assisting the councils to carry out 
governance assignments. This study will face a main question raised from theories and previous studies which are do the work experience, positioning, the level on independence and the risk identification on promoting effect on corporate governance by using the management support in commercial Iraqi banks?

The general objective of the paper is to evaluate the internal audit function in promoting effective corporate governance among commercial banks in Iraq. While The specific objectives of the study are to analyze the impact of work experience, the positioning, level of independence and the risk identification, measurement and prioritization approach by using Management Support adopted to internal audit function of commercial banks in Iraq. The significance of the study throughout the world in the past two decades the financial industry in general and the banking sector, in particular, has witnessed significant developments including the consolidation of institutions, the globalization of operations, and the introducing of new technologies. The findings of this study will help internal auditors, management in MFIs, academicians, and students of various fields in gaining more knowledge on the use, importance and need for internal audit in promoting good corporate governance structures. The study will contributes to stakeholder theory, which states that the duties of corporations extend to all stakeholders and not only shareholders. The contribution of the study is first Provideing insights to improve the internal audit function in commercial banks which is an integral part of corporate governance reporting since it directly affects the interests of all stakeholders such as customers, suppliers, employees, creditors and government agencies, second highlighting the need to change the outlook of the bank staff towards the internal audit function bearing in mind the importance of strong internal audit function for the growth of Commercial Banks which are beneficial for the development of Iraq economy.

\section{LITERATURE REVIEW}

\section{Internal Audit}

Internal audit is the examination, monitoring and analysis of activities related to a company's operation, including its business structure, employee behavior and information systems. It is designed to review what a company is doing in order to identify potential threats to the organization's health and profitability, and to make suggestions for mitigating the risk associated with those threats in order to minimize costs. Another ddefinition of Internal auditing is an independent, objective assurance and consulting activity designed to add value and improve an organization's operations. It helps an organization accomplish its objectives by bringing a systematic, disciplined approach to evaluate and improve the effectiveness of risk management, control, and governance processes. To do this, internal auditors work with management to systematically review systems and operations by Barua, Rama, and Sharma (2010)\&Norman, Rose, and Rose (2010).

Typically, the main role of audit committee was, almost exclusively, to supervise the financial reporting process. However, recently, within the corporate governance system, audit committee's role has become, in general, concerned with all aspects of corporate governance. As such, the role of audit committee in corporate governance encompasses duties and responsibilities in a number of areas such as financial statements and reporting, evaluation of internal audit and the internal control systems, external audit planning, risk management, and environmental management systems (e.g. Abdul Saleh 2014; Al-Mudhaki \& Joshi 2004).

Gramling et al. (2004) performed a literature review on the role of internal auditing in corporate governance. This review found that the role of an internal audit function in corporate governance has been analyzed using the external auditors' evaluation of its quality, determinants of its reliance decision, the extent and nature of its work relied on by the external auditor and other aspects of the external audit (Gramling et al. 2004). The Professional Practices Framework 
in the Institute of Internal Auditors (IIA) Research Foundation (2004) defines 'Internal Auditing as 'an independent, objective assurance and consulting activity designed to add value and improve an organization's operations. It helps an organization accomplish its objectives by bringing a systematic, disciplined approach to evaluate and improve the effectiveness of risk management, control, and governance processes.

\section{Corporate governance}

Corporate governance is defined as "the system by which companies are directed and controlled" (Cadbury Committee 1992, p. 15). Later in 1999, the Organization for Economic Cooperation and Development (OECD) introduced this definition "Corporate governance involves a set of relationships between a company's management, its board, its shareholders and other stakeholders. Corporate governance also provides the structure through which the objectives of the company are set, and the means of attaining the objectives and monitoring performance are determined" (OECD 1999). Accordingly, it can be said that the corporate governance concept relates to a wide range of activities, rules, guidelines, processes and procedures that aim to ensure that the companies' resources are optimally managed and employed by boards of directors which will, in turn, lead to achieve the stated objectives of the companies and eventually protect the interests of corporate stakeholders in particular and the society as a whole (Abdul Saleh 2014).

Recent research in corporate governance finds that multiple corporate governance perspectives can help to explain and understand the complexities faced by corporate governance actors, along with these actors' motivations and behaviors (e.g. Beasley et al., 2009; Cohen et al., 2010; Hermanson et al., 2012). This thesis considers these key perspectives of governance to help understand internal audit function stakeholders' judgments of IAF quality and their reliance on internal audit function information. Judgments and perceptions of quality are likely to vary considering the organizational perspective that drives the corporate governance process (Cohen et al., 2008). Kyereboah-Coleman (2007) found that large and independent boards enhance firm value and that combining the positions of chief executive officer and board chair has a negative impact on corporate performance. Boards and indeed top managers have a critical role in the strategic direction and success of organizations.

\section{Work Experience}

Considering the literature about the measurement of auditing effectiveness particularly in the public sector, there are more studies needed to be done (Mizrahi \& Ness-Weisman, 2007). Similarly, earnings quality of both public and private companies is increasing in audit experience (Chi et al, 2010). This is because auditors that have experience tend to perform best audit practices in order to achieve better audit outcomes that would lead to audit success due to their abilities to react to their clients' expectations, needs and the requirements due to their awareness to various auditing standards and practice (Ussahawanitchakit, 2012).

Zain, Subramaniam \& Goodwin (2004), argued that the size of the internal audit function as well as the extent of prior audit experience of the internal audit staff are likely to enhance the quality of the internal audit. Zain et al., (2004), explained that in a larger internal audit unit, there will be more staff and consequently it can be expected that the scope of the internal audit work covered would be much greater than in a smaller sized unit.

\section{Independence}

The present literature shows that the assurance focus of internal auditing promotes internal audit independence (J Christopher et al., 2009; Jenny Goodwin \& Yeob, 2001); whereas, the consulting paradigm advocates the notion that internal audit operates as a partner of management 
(Bou-Raad, 2000; J Goodwin, 2004; Roth, 2000, 2002). Nevertheless, the literature shows contemporary internal auditing has been embracing the consulting focus in its role (Cooper, Leung, \& Wong, 2006) while the traditional compliance focus remains evident as well (Allegrini, Paape, Meville, \& Sarens, 2006; Haas, Abdolmohammadi, \& Burnaby, 2006; Mihret \& Yismaw, 2007).

Similar patterns exist elsewhere. In Canada, the Canadian Securities Administration and the Canadian accounting professional body are also requiring more disclosure on internal controls (Anonymous, 2004a; Spira and Page, 2002, p. 648). The UK Accounting Standards Board (ASB) has expressed concern with operational events since the Cadbury Report (1992) and carry on with, for example, the Turnbull Reports (Anonymous, 2004b, Vinten, 2001). Overall, the eyes of the public are more firmly fixed on the functions traditionally associated with internal audit activity and how those auditors convey that information to their governing authority. The need for an ethical, reasonably independent and competent internal, as well as external, auditor is thus affirmed.

\section{Positioning}

An internal audit function could be viewed as a first line of defense against inadequate organizational governance and financial reporting. With appropriate support from the board and audit committee, the internal audit is in the best position to gather intelligence on inappropriate accounting practices, inadequate internal controls and ineffective corporate governance (Zekele, 2007).

Internal auditors may not always be in a strong position to do so, however (see Altwaijry, Brierley and William, 2004; Glasscock, 2002). An Australian survey concluded, for example, that internal auditors may not be seen as a 'true profession' by all, including some of their own corporate managers (Cooper, Leung and Mathews, 1994). This can result in less value being attributed to their services or to their views than those of so-called 'external' auditors. An internal audit position is seen by many as little more than a corporate training ground for managers (Cooper, Leung and Mathews, 1994; Goodwin and Yeo, 2001). Brody and Lowe (2000) found it likely that, as a result, internal auditors will become more involved with top management as consultants rather than as independent assessors.

\section{Risk}

Internal auditors play a key role in monitoring a company's risk profile and identifying areas to improve risk management (Goodwin-Stewart and Kent 2006). In the 1950s and 1960s, it only consisted of basic test of the accounts with a view to isolating errors and irregularities. In contrast, today's internal auditors facilitate the development of suitable controls as part of a wider risk strategy and provide assurances on the reliability of these controls. The move from detailed low-level checks of huge volume of mainly transactions to high-level put into corporate risk management has been tremendous (Rudasingwa, 2006) Ernst and Young's (2006) third Australasian benchmarking survey indicates that $62 \%$ of respondents' internal audit functions are involved in providing assurance over risk management practices, while $47 \%$ report that internal audit develops and assists in the oversight of the risk management framework.

Fraser and Henry (2007) undertook a series of interviews of the finance director, the audit committee chair, and, where applicable, the head of internal audit and the director of risk management in five large UK organizations, as well as an audit partner of from each of the Big Four audit firms. They found that internal audit tends to play a major role in ERM, particularly in the embedding of risk. More interestingly, they also found evidence of internal auditors having responsibility for ERM practices, despite the COSO and IIA position paper stating that 
responsibility must rest with management. According to Mihret \& Yismaw (2007), audits plans enable the audit staff to evaluate risk and identify high-risk areas that deserve audit attention. An effective internal audit function require the head of the internal audit office to periodically report to top management or audit committee on the internal audit activity's purpose, authority, responsibility and performance relative to its plan.

\section{Management Support}

Management Support: Top management has an important say in the resources devoted to the internal audit units. They are also likely to give input to the internal audit work plan which provides the internal audit department with the empowerment required for it to perform its duties and responsibilities, Meckling and Jensen (1976) in their paper on the theory of the firm defined the agency relationship as a contract under which one or more persons engage another person (the agent) to perform some service on their behalf which involves delegating some decision making authority to the agent. Thus, for the internal audit to be effective there is need for not only their independence but also the top management support. Management's support is probably the most important factor in a company environment. the effectiveness of internal auditing department mostly depends on management involvement and requirement, the attitude of the board of directors, in addition, the Statements of Internal Auditing Standards regulates that the head of internal auditing should communicate directly with the board of directors regularly, and they should meet with each other without management on the scene at least once a year, enhance the independence of internal auditing. if management provides internal auditing department with an independent position inside an organization, it would have a positive influence on control environment(Asaolu, Adedokun, and Monday 2016).

\section{THEORETICAL FRAMEWORK AND HYPOTHESES DEVELOPMENT Corporate Governance Framework:}

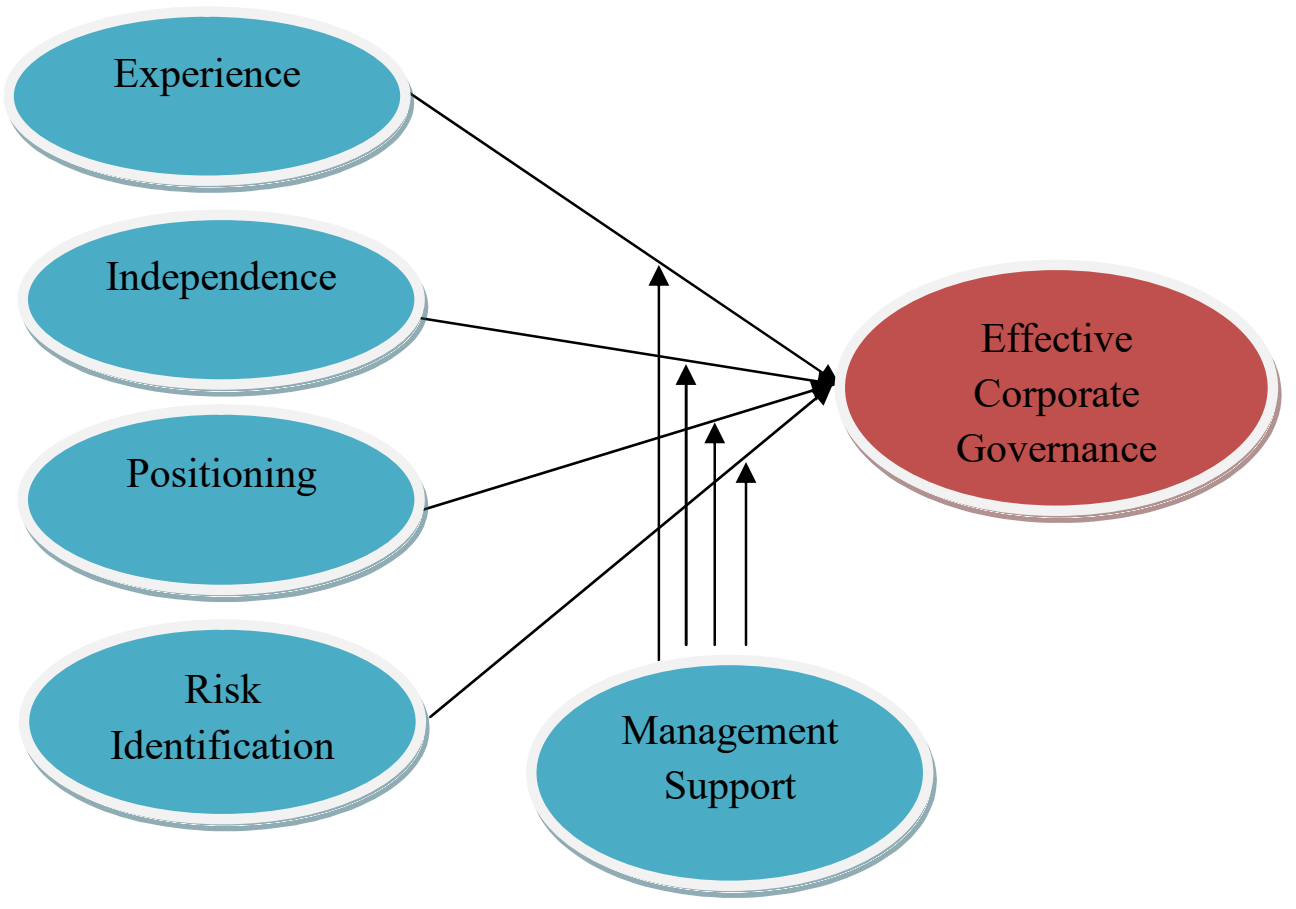

Vol. 25, No. 2/ December 2017 


\section{Theoretical Framework}

Agency Theory

The principles of agency theory will be used to evaluate these relationships. Applying a financial-economics-based theory such as 'agency' is of value both to understand an aspect of organizational practice, and to influence the manner in which management plans, establishes and maintains control systems (San Miguel, 2002). Though, it is not widely applied to internal audit, agency theory has been suggested as a useful basis to analyze why some organizations have internal audit departments and others do not, to examine how organizational change affects internal audit departments and to evaluate how or why internal audit departments vary in the way they do (Adams, 1994). Agency theory has been applied to determine why some public accountants contract for internal auditing (Caplan and Kirschenheiter, 2000) and to examine moral hazards within management systems of different cultures (Ekanayake, 2004; Evans, 2003).

In most of the literature, the agency theory deals with the relationship between the owner/shareholder of a firm and the chief executive officer (Jensen \& Meckling, 1976). In this view, ownership is widely held by shareholders - at least, in US jurisdiction, but not in German, French and Dutch jurisdiction - and managerial actions deviate from the required maximization of shareholder returns (Pratt \& Zeckhauser, 1985). On the other hand, Fama (1980) and Pratt \& Zeckhauser (1985) utilized the principal-agent theory to examine the hierarchical inter-manager relationships that exist within large firms. In this context, the firm's chief executive officer is viewed as the principal who attributes decision rights to the lower level management (agents), and thus inducing agency costs due to information asymmetry.

Agency theory suggests that boards should consist of outside and independent directors. It also proposes that the positioning of the board chairman and chief executive officer should be separate (Daily and Dalton, 1992; Balta, 2008). When the separation of those two roles is violated, mainly when the chairman is under the influence of the chief executive officer, the agency cost becomes great and the firm will suffer in the financial and control market (Dalton et al., 1999; Balta, 2008). Although Agency Theory is the dominant perspective in corporate governance studies, it has been criticized in recent years (Blair, 1996; Hoskisson et al., 2000; Fan, 2004) because of its limited ability to explain sociological and psychological mechanisms inherent of the principal-agent interactions (Davis, 1991).

To minimize the potential for such agency problems, Jensen (1983) recognizes two important steps: first, the principal-agent risk-bearing mechanism must be designed efficiently and second, the design must be monitored through the nexus of organizations and contracts. The first step, considered as the formal agency literature, examines how much of risks should each party assume in return for their respective gains. The principal must transfer some rights to the agent who, in turn, must accept to carry out the duties enshrined in the rights. The second step, which Jensen (1983, p. 334) identifies as the 'positive agency theory', clarifies how firms use contractual monitoring and bonding to bear upon the structure designed in the first step and derive potential solutions to the agency problems. The inevitable loss of firm value that arises with the agency problems along with the costs of contractual monitoring and bonding are defined as agency costs (Jensen and Meckling, 1976).

\section{Stewardship Theory}

Stewardship theory is a framework which argues that people are intrinsically motivated to work for others or for organizations to accomplish the tasks and responsibilities with which they have been entrusted. It argues that people are collective minded and pro-organizational rather than individualistic and therefore work toward the attainment of organizational, group, or societal goals because doing so gives them a higher level of satisfaction. Stewardship theory therefore provides one framework for characterizing the motivations of managerial behavior in various types of organizations. 
In contrast to agency theory, stewardship theory posits that managers are essentially trustworthy individuals and so are good stewards of the resources entrusted to them (Donaldson, 1990; Donaldson and Davis, 1991; 1994). Since inside (or executive) directors spend their working lives in the company they govern, they understand the businesses better than outside directors and so can make superior decisions (Donaldson, 1990; Donaldson and Davis, 1991; 1994). As a result, proponents of stewardship theory contend that superior corporate performance will be linked to a majority of inside directors as they naturally work to maximize profit for shareholders.

The 'model of man' in Stewardship Theory is someone whose behavior is ordered such that pro organizational behaviors have higher utility than individualistic behaviors (Davis et al., 1997). This model of man is rational as well, but perceives greater utility in cooperative behaviors than in self-serving behaviors. A steward's utility function is maximized when the shareholders' wealth is maximized. The steward perceives that the utility gained from interest alignment and collaborative behavior with the principal is higher than the utility that can be gained through individualistic, self-serving behaviors (Davis et al., 1997). Stewards are motivated by intrinsic rewards, such as reciprocity and mission alignment, rather than solely extrinsic rewards. The steward, as opposed to the agent, places greater value on collective rather than individual goals; the steward understands the success of the company as his own achievement. Therefore, the major difference between both theories is on the nature of motivation. Agency Theory places more emphasis on extrinsic motivation, while Stewardship Theory is focused on intrinsic rewards that are not easily quantified, such as growth, achievement, and duty.

Furthermore, stewardship theory suggests the motives of the corporate governance actor are aligned with objectives of the organization and the actor has a focus on promoting value and organizational improvement (Beasley et al., 2009; Davis et al., 1997). Stewardship theory incorporates alternative behavioral principles than agency theory by suggesting behavior does not depart from the organizations interests (Davis et al., 1997). The behavioral principles are based on two premises: first, that the steward is naturally honest and trustworthy, motivated to do the best for the organization and not for personal gain; and second, actors behave in an entrusting manner to not jeopardize their reputation (Nicholson and Kiel, 2007). Therefore this theory challenges the agency theory perspective (Nordberg, 2011, p. 45) and the distinction is that motivation under an agency perspective is extrinsic, versus intrinsic motivation under stewardship.

\section{Hypotheses Development}

\section{The Effect of Experience on Internal Audit Function in Corporate Governance.}

Libby and Frederick (1990) suggested that this knowledge advantage is as a result of the ability to generate more likely explanations for audit findings. This leads the earlier researchers suggest that when an auditors gain experience, it's an indication that; they know more about errors; they have more accurate knowledge on error; they know more occasional errors, and the causes features of errors. However, Bonner and Lewis (1990) argued that even though experience is a good predictor of knowledge, but not all types of knowledge are acquired equally by persons with a given amount of experience. Likewise not all persons with similar experience in a domain are likely to have similar problem solving abilities but rather it depend on the task or clients activities and because the different types of knowledge are acquired through different specific experiences and training.

H1: Experience has positive effect of corporate governance. 


\section{The Effect of Independence Internal on Audit Function in Corporate Governance}

According to Millichamp, (2002), the internal auditors should be placed in the organisational pattern of a business with independence in mind. Being bound more closely to its company than an external auditors bound to their clients, the internal auditing department enjoys a somewhat smaller degree of independence as compare to external auditor. The internal auditors work under the direction of the management of an organisation or institution and they may be concerned with areas of managerial control. The objectives, therefore, is to assist management in the effective discharge of their responsibilities.

The level of contribution that internal auditors can make in improving risk management and organisational performance depends on its status in the organisation. The internal audit function of an organisation should be given a sufficiently high status in the organisational structure to enable better communication with top management and to ensure independence of internal auditor from auditees (Mihret Yismaw 2007).

H2: Independence has positive effect of corporate governance.

\section{The Eeffect of Positioning on Internal Audit Function in Corporate Governance}

Internal auditors may not always be in a strong position to do so, however (see Altwaijry, Brierley and William, 2004; Glasscock, 2002). An Australian survey concluded, for example, that internal auditors may not be seen as a 'true profession' by all, including some of their own corporate managers. This can result in less value being attributed to their services or to their views than those of so-called 'external' auditors. An internal audit position is seen by many as little more than a corporate training ground for managers (Cooper, Leung and Mathews, 1994; Goodwin and Yeo, 2001).

H3: Positioning has positive effect of corporate governance

\section{The Effect of Risk on Internal Audit Function in Corporate Governance}

Internal auditors play a key role in monitoring a company's risk profile and identifying areas to improve risk management (Goodwin-Stewart and Kent 2006). The aim of internal auditing is to improve organisational efficiency and effectiveness through constructive criticism. IA has four main components: (1) verification of written records; (2) analysis of policy; (3) evaluation of the logic and completeness of procedures, internal services and staffing to assure they are efficient and appropriate for the organisation's policies; and (4) reporting recommendations for improvements to management (Eden and Moriah 1996).

H4: Risk has positive effect of corporate governance

\section{The Moderating Effect of the Management Support on Internal Audit Function in Corporate Governance}

Alzeban (2014) examined the effectiveness of the internal audit function within Saudi Arabia government. The study noted that there were factors that contributed to the perceived effectiveness of the internal audit function in Saudi Arabia including competence, independence, size of the function, the relationship between internal and external audit and the extent of management support for the internal audit function and also as to the role of management support for the internal audit function as a key driver of the effectiveness of the function. In the context of Malaysia, Hammad et al., (2012) the lack of qualified, skilled and experienced internal auditors greatly reduced the effectiveness of the internal audit function within the public sector in Malaysia. There were few internal auditors in the government with 10 years of experience.

Masika (2013) examined the effect of the risk based internal auditing on the effectiveness of the internal audit in regulatory state corporations in Kenya. The study concluded that the internal audit in RSCs in Kenya has strived and attained a good level of effectiveness. However, 
there were noted weaknesses in management support of the internal audit function, as well as the ability of the internal audit function to capture the needs of the management.

H: 6a The Management Support strengthens the relationship between Experience and Internal Audit Function in Corporate Governance.

H: 6bThe Management Support strengthens the relationship between Independence and Internal Audit Function in Corporate Governance.

H: $6 \mathrm{c}$ The Management Support strengthens the relationship between Positioning and Internal Audit Function in Corporate Governance.

H: 6d The Management Support strengthens the relationship between Risk and Internal Audit Function in Corporate Governance.

\section{REFERENCES}

Abdulsaleh, A. (2014), "Corporate Governance Role of Audit Committees in the Banking Sector: Evidence from Iraq", Paper presented at the International Conference on Finance, Banking and Insurance, Rio de Janeiro, Brazil.

Adams, M. B. (1994). Agency Theory and the Internal Audit. Managerial Auditing Journal. 9(8), 8-12.

Al-Mudhaki, J., \& Joshi, P. L. (2004), "The Role and Functions of Audit Committees in the Indian Corporate Governance: Empirical Findings", International Journal of Auditing, 8(1), 33-47.

Al-Twaijry, A. A. M, Brierley, J.A., \& Gwilliam, D.R. (2003). The development of internal audit in Saudi Arabia: An Institutional Theory perspective. Critical Perspective on Accounting, 14, pp. 507-531. doi:10.1016/S1045-2354(02)00158-2.

Al-Twaijry, A. A. M., Brierley, J.A., \& Gwilliam, D. R. (2004). An examination of the relationship between internal and external audit in the Saudi Arabian corporate sector, Managerial Auditing Journal, 19(7), 929-944.

Al-Twaijry, A.A.M., Brierley, J.A. and Gwillian, D.R. 2003, 'The Development of Internal Audit in Saudi Arabia: An Institutional Theory Perspective', Critical Perspectives on Accounting, 14: 507-531.

Balta ME (2008). The Impact of Business Environment and Boards of Directors on Strategic Decision - Making: A Case Study of Greek Listed Companies, Unpublished PhD Thesis, Brunei Business School.

Balta ME (2008). The Impact of Business Environment and Boards of Directors on Strategic Decision - Making: A Case Study of Greek Listed Companies, Unpublished PhD Thesis, Brunei Business School.

Beasley, M. S., J. V. Carcello, D. R. Hermanson, and T. L. Neal. 2009. The Audit Committee Oversight Process. Contemporary Accounting Research 26 (1):65-122.

Beasley, M. S., J. V. Carcello, D. R. Hermanson, and T. L. Neal. 2009. The Audit Committee Oversight Process. Contemporary Accounting Research 26 (1):65-122.

Blair M (1996).Ownership and Control: Rethinking Corporate Governance for the Twenty-first Century, Brookings Institution, Washington.

Bou-Raad, G. (2000), "Internal auditors and the value added approach: the new business regime", Managerial Auditing Journal, Vol. 15 No. 4 pp. 183-186.

Bou-Raad, G. 2000, 'Internal Auditors and a Value-added Approach: The New Business Regime', Managerial Auditing Journal, 15: 182-86.

Brody, R. G., \& Lowe, D. J. (2000). The New Role of the Internal Auditor: Implications for Internal Auditor Objectivity. International Journal of Auditing, 4, 169-176. 
Cadbury Committee. (1992), "Report of the Committee on the Financial Aspects of Corporate Governance", London, Professional Publishing Ltd.

Caplan, D. H., \& Kirschenheiter, M. (2000). Outsourcing and Audit Risk for Internal Audit Services. Contemporary Accounting Research. 17(3), 387-428.

Christopher, J., Sarens, G. and Leung, P. (2009), "A critical analysis of the independence of the internal audit function: evidence from Australia", Accounting, Auditing \& Accountability Journal, Vol. 22 No. 2, pp. 200-220.

Cohen, J., G. Krishnamoorthy, and A. M. Wright. 2008. Form Versus Substance: The Implications for Auditing Practice and Research of Alternative Perspectives on Corporate Governance. Auditing: A Journal of Practice \& Theory 27 (2):181-198.

Cohen, J., G. Krishnamoorthy, and A. Wright. 2010. Corporate Governance in the Post-SarbanesOxley Era: Auditors' Experiences. Contemporary Accounting Research 27 (3):751-786.

Cooper, B. J., Leung, P., \& Mathews, C. (1994). Internal Audit: An Australian Profile. Managerial Auditing Journal, 9(3), 13-19.

Daily CM, Dalton DR (1992). The Relationship between Governance Structure and Corporate Performance in Entrepreneurial Firms.Journal of Business Venturing, Vol. 7, No.5. pp. 375-386.

Dalton DR, Daily CM, Johnson L, Ellstrand A (1999). Number of Directors and Financial Performance: A Meta-Analysis. Aca. Manage. J., 42:. 674-686.

Davis JH (1991). Board Leadership Roles and Shareholder Returns: An Examination ofAgency, Doctoral Dissertation, The University of Iowa. Fama E, Jensen M (1983). Separation of Ownership

Davis, J. H., F. D. Schoorman, and L. Donaldson. 1997. Toward a Stewardship Theory of Management. Academy of Management Review 22 (1):20-47.

Davis, J. H., Schoorman, F. D. and Donaldson, L. (1997). - Toward a Stewardship Theory of Managementll, Academy of Management Review, 22(1): 20-47.

Davis, J.H., Schoorman, F.D., \& Donaldson, L. 1997. Academy of Management Review, 22: 2047.

Donaldson, L. (1990) The ethereal hand: organizational economics and management theory, Academy of Management Review, 15(3), 369-381.

Donaldson, L. and Davis, J. H. (1991) Stewardship theory or agency theory: CEO governance and shareholder returns, Australian Journal of Management, 16(1), 49-64.

Donaldson, L. and Davis, J. H. (1994) Boards and company performance - research challenges the conventional wisdom, Corporate Governance: An International Review, 2(3), 151160.

Ekanayake, S. (2004). Agency theory, national culture and management control systems. Journal of American Academy of Business, 4/1-2, 49-54.

Ernst \& Young. 2006. Trends in Australian and New Zealand internal auditing. Third annual benchmarking survey 2006. Australia: Ernst \& Young.

Evans, L. (2003). Auditing and audit firms in German before 1931. The Accounting Historians Journal, 30(2), 29-65.

Fama, E. (2006). Agency Problems and the Theory of the Firm. Journal of Political Economy, 88(2), 288-307.

Fama, E. F. 1980. Agency Problems and the Theory of the Firm. Joumal of Political Economy 88(2): 288-307.

Fan PS (2004). Review of Literature and Empirical Research on Corporate Governance By Financial Services Group Training Unit Monetary Authority of Singapore. Monetary Authority of Singapore (MAS) Staff Paper 
Fraser, I., and W. Henry. 2007. Embedding risk management: Structures and approaches. Managerial Auditing Journal 22 (4): 392-409.

Glasscock, K. L. (2002). Auditees or clients? The Internal Auditor, 59(4), 8485.

Goodwin, J. (2004). A comparison of internal audit in the private sector and public sector. Managerial Auditing Journal, 19(5),640-650.

Goodwin, J. and T.Y. Yeo. 2001. Two factors affecting internal audit independence and objectivity: Evidence from Singapore. International Journal of Auditing 5: 107-125.

Goodwin-Stewart, J. and Kent, P. 2006, 'The Use of Internal Audit by Australian Companies', Managerial Auditing Journal, 21: 81-101.

Gramling, A. A., M. J. Maletta, A. Schneider, and B. K. Church. 2004. The role of the internal audit function in corporate governance: A synthesis of the extant internal auditing literature and directions for future research. Journal of Accounting Literature 23: 194244.

Hermanson, D. R., J. G. Tompkins, R. Veliyath, and Z. Ye. 2012. The Compensation Committee Process. Contemporary Accounting Research 29 (3):666-709.

Hoskisson RE, Eden L, Lau CM, Wright M (2000). 'Strategy in Emerging Economies', Aca. Manage. J., 43(3): 249-267.

Jensen, M. C., \& Meckling, W. H. 1976. Theory of the Firm: Managerial Behavior, Agency Costs, and Ownership Structure. Journal of Financial Economics, 4(October): 305-360.

Kyereboah-Coleman A (2007). Corporate Governance And Firm Performance In Africa: A Dynamic Panel Data Analysis, A Paper Prepared for the "International Conference on Corporate Governance in Emerging Markets"

Lewis, A. and Collins, J. (1990). "Ethical Investments: Preference and Morality", The Journal of Behavioural Economics, 19: 395-411.

Mat Zain, M. and N. Subramaniam. 2007. Internal auditor perceptions on audit committee interactions: A qualitative study in Malaysian public corporations. Corporate Governance: An International Review, Accepted, March.

McGregor, D. (1960) The human side of enterprise. New York: McGraw-Hill. May, T. (1997) Social research: Issues, methods and process, 2nd edn. Philadelphia: Open University Press.

McNamee, D., \& Selim, G. M. 1998. Risk Management: Changing the Internal Auditor's Paradigm. Altamonte Springs, FL: The Institute of Internal Auditors Research Foundation.

Mihret, D.G., \& Yismaw, A. W.(2007). Internal audit effectiveness: An Ethiopian public sector case study. Managerial Auditing Journal, 22(5), 470-484.

Nanni, A.J. 1984, 'An Exploration of the Mediating Effects of Auditor Experience and Position in Internal Accounting Control Evaluation', Accounting, Organizations and Society, 9: 149-63.

Nicholson, G. J., and G. C. Kiel. 2007. Can Directors Impact Performance? A Case-Based Test of Three Theories of Corporate Governance. Corporate Governance: An International Review 15 (4):585-608.

Nordberg, D. 2011. Corporate Governance: Principles and Issues. Los Angeles: Sage. O'Reilly, C. A., III. 1982. Variations in Decision Makers' Use of Information Sources: The Impact of Quality and Accessibility of Information. Academy of Management Journal 25 (4):756-771.

Pratt, J. W., \& Zeckhauser, R. J. 1985. Principals and agents: the structure of business. Boston: Harvard Business School Press.

Raffournier, B. (1995). The determinants of voluntary financial disclosure by Swiss listed companies. The European Accounting Review, 4(2), 261-280. 
Rudasingwa, J.(2006). The Role of the internal audit function in enhancing risk management in the Rwanda Social Security Fund.

Said, R., Zainuddin, Y. H. Z., and Haron, H. (2009). The relationship between corporate social responsibility disclosure and corporate governance characteristics in Malaysian public listed companies. Social Responsibility Journal, 5(2), 212-226.

San Miguel, J. G. (2002). The Behavioral Sciences and Concepts and Standards for management Planning and Control. Accounting, Organizations and Society. 2(2), 177-186.

Sarens, G. and Beelde, I. (2006), "The relationship between Internal Audit and Senior Management: A Qualitative Analysis of Expectations and Perceptions", International Journal of Auditing, Vol. 10, pp. 219-241.

Spira, L. F., \& Page, M. (2002). Risk management: The reinvention of internal control and the changing role of internal audit. Accounting, Auditing \& Accountability Journal, 16(4), 640-661.

Zain, M. M., Subramaniam, N. P., \& Goodwin, J. (2004).Audit committee and internal audit function characteristics: Impact on internal audit

Zain, M. M., Subramaniam, N. P., \& Goodwin, J. (2004).Audit committee and internal audit function characteristics: Impact on internal audit contribution to financial statement. Managerial Auditing Journal, 20-25.

Zekele, B. (2007). A study on Effective Implementation of Internal Audit Function to Promote Good Corporate Governance in the Public sector. Ethiopia Civil Service Research and Consultancy Coordination's Office.

Masika, P. (2013). The Effect of the Quality of Risk Based Internal AQuditing on the Effectiveness of Internal Audit in Regulatory State Corporations in Kenya. Journal of Sustainable Development in Africa, 2(3), 12-15.

Hammad, M., Awan, S. H., Akhtar, C. S., \& Imdadullah, M. (2012). Factors that Contribute to the Effectiveness of Internal Audit in Public Sector. International Proceedings of Economics Development and Research, 55(28), 141-144.

Alzeban, A. (2014). Perceptions of Managers and Internal Auditors as to Factors Affecting the Effectivness of Internal Audit in the Public Sector Context. International Journal of Business and Social Sciences, 2(3), 17-20. 